\title{
SMALL EFFORT, BIG RESULTS: THROWING AND CATCHING ACTIVITIES USING PLASTIC BALL TO FOSTER CHILD'S KINESTHETIC ABILITY
}

\author{
Adrianus Krobo \\ Universitas Cendrawasih Papua, Indonesia \\ Corresponding e-mail: krobozon@gmail.com
}

\begin{abstract}
The purpose of this study was to improve the kinesthetic ability of group A, Ria Pembangunan Kindergarten, Sentani, Jayapura through a throwing-catching game using the small plastic ball. This research uses the action research method. Participants were collected using purposive sampling by involving 12 children in group A. Kinesthetic ability is one aspect that plays an essential role in child development. In the first cycle, the results showed that the child's kinesthetic ability reached $49.30 \%$, including throwing with one hand over the shoulder, reaching $45.83 \%$, throwing with one hand below $52.08 \%$, and catching the ball $50 \%$. As for the second cycle, it increased to $82.64 \%$, including throwing with one hand over the shoulder, reaching $81.22 \%$, throwing with one hand below, reaching $85.42 \%$, and the aspect of catching the ball reaches $83.33 \%$. Thus, the results showed that throwing-catching games using small plastic balls could improve the kinesthetic ability of group A at Ria Pembangunan Sentani Kindergarten, Jayapura Regency, Papua.
\end{abstract}

Keywords: kinesthetic ability, throwing and catching, plastic ball play

\begin{abstract}
Abstrak
Tujuan dari penelitian ini adalah untuk meningkatkan kemampuan kinestetik kelompok A TK Ria Pembangunan Sentani Kabupaten Jayapura melalui permainan lempar tangkap bola plastik kecil. Penelitian ini menggunakan metode action research. Partisipan dikumpulkan menggunakan purpossive sampling dengan melipatkan 12 anak di TK A. Kemampuan kinestetik merupakan salah satu aspek yang berperan penting dalam perkembangan anak. Hasil penelitian menyatakan bahwa pada siklus I kemampuan kinestetik anak mencapai 49.30\%, meliputi aspek melempar dengan satu tangan di atas bahu mencapai 45.83\%, aspek melempar dengan satu tangan di bawah $52.08 \%$, dan aspek menangkap bola 50\%. Adapun pada siklus II mengalami peningkatan menjadi 82.64\%, meliputi aspek melempar dengan satu tangan di atas bahu mencapai $81.22 \%$, aspek melempar dengan satu tangan di bawah mencapai $85.42 \%$, dan aspek menangkap bola mencapai 83.33\%. Hasil penelitian menunjukkan bahwa permainan lempar tangkap bola plastik dapat meningkatkan kemampuan kinestetik kelompok A TK Ria Pembangunan Sentani Kabupaten Jayapura Papua.
\end{abstract}

Kata Kunci: kemampuan kinestetik, tangkap dan lempar, bermain bola plastik 


\section{Introduction}

About $40 \%$ of human development occurs at an early age (Khaironi, 2018). Early childhood is an individual who is experiencing a process of rapid development. Early childhood education is all efforts made by educators and parents in the care, upbringing, and education. Children will obtain real experience through several activities by observing, imitating, and repeatedly experimenting by involving all their potential and intelligence (Sujiono \& Nurani, 2008). Parents are expected to optimize their children's because, at this age, children's development can grow and develop optimally (Respati et al., 2018).

The proper stimulation is needed to achieve optimal development. Success at the age of $0-8$ years is the foundation for the next stage of development. Therefore, if the child does not get the proper stimulation during the golden age through training and learning, it can be estimated that the child will have difficulties in the next stage or phase of development (Dinar, 2008).

Some people prioritize intellectual development over physical ability development (Safitri et al., 2020; Syaikhu \& Napis, 2020). For example, parents prioritize that their children can speak, read, and write well rather than doing physical activities well (Rosmayanti et al., 2021). In contrast, physical activity is an important thing that must be optimized during a child's development (Ali et al., 2017; Bellows et al., 2017; Hasibuan et al., 2020; Logan et al., 2012; Mukherjee et al., 2017). In addition, kinesthetic ability combines physical and mind to produce perfect movement (Fitriana et al., 2021; Musfiroh, 2008; Nursiti et al., 2020).

Kinesthetic development should be carried out in a structured and ideal manner to support children's physiological and psychological development (Junaedi \& Nugroho, 2014; Rochimah et al., 2020). Through kinesthetic development, children can improve their psychomotor abilities, skills, self-confidence, creativity, and health. This ability begins with the formation of reflexes and simple motor skills, which then develops into the ability to control movement, speed, balance, dexterity, flexibility, strength, and the motion that can be done in everyday life (Brian \& Taunton, 2018; Farmer et al., 2017; Rahayu \& Firmansyah, 2019; Rohmah \& Jauhari, 2020; Utesch et al., 2019).

Previous research stated that dancing, rhythmic gymnastics, and playing some traditional games could improve children's kinesthetic abilities (Sobariah \& Santana, 2019; Viana \& Jauhari, 2017; Wahyuni et al., 2020; Yetti \& Juniasih, 2016; Yuningsih et al., 2019). Several other studies argue that role-playing activities, physical skill training, and sports such as swimming, mini soccer, mini tennis balls, and mini basketballs can also improve kinesthetic abilities in children (Sujiono \& Nurani, 2008; 
Yuningsih et al., 2019). Those activities mainly involve physical skills, where to play a role in improving the health and development of children (Umami et al., 2016; Utesch et al., 2019).

The movement of throwing and catching the ball is part of several movements that can develop kinesthetic abilities in children. The throwing action is a motion with a forward step on the same side as the throwing arm. While catching is a movement that requires eye and hand coordination to track the thrown ball and catch it by the hand (Beaty, 2013). Throwing and catching a ball is one of the basic movements that early childhood needs to be mastered by early childhood because this manipulation movement beneficial for children's kinesthetic development (Kamtini \& Husni, 2005; Rozie et al., 2019).

This study aims to explain that catching-throwing using small plastic balls can develop children's kinesthetic abilities. This study also aims to provide an overview of activities that can be applied by teachers and parents both in the learning process or activities at home that can improve children's kinesthetic development.

\section{Method}

This research uses action research methods. This study aims to improve children's kinesthetic abilities through a small plastic ball. This research was conducted at Ria Pembangunan Kindergarten Jl. Sentani Airport, Sentani City, Sentani District, Jayapura Regency, Papua Province. The research was conducted during the fall semester of the 2019-2020 academic year. The object of research involved twelve students of class A at Ria Pembangunan Kindergarten, Sentani. The instrument used is an increase in kinesthetic ability through observations using a rating scale. The indicators are as follows. 1) The child can throw with one hand above the shoulder, 2) The child can throw with one hand under the shoulder, and 3) The child can catch the ball using hands.

This research was conducted by using two cycles of action. Meanwhile, data compilation was carried out through cycle analysis and reflection based on observations recorded in field notes and other observation formats and ended in data reduction and concluding.

Quantitative analysis uses scoring students individually and calculating percentages. The percentage results will be described according to the indicators per child. This study confirms the successfulness indicator by looking at the percentage of kinesthetic intelligence assessment per aspect in children, and it is increasing by a minimum percentage of $75 \%$. 


\section{Results and Discussion}

Learning processes at Ria Pembangunan Sentani Kindergarten are carried out according to a systematic thematic arrangement through the lesson plans regarding improving kinesthetic abilities in cycles I and II. At first, the percentage of the initial research results had not reached the expected target and was agreed upon by the researchers and collaborators. Then, the implementation of reflection is presented to fix everything that needs to be done in the following step. Therefore, the researcher and collaborator teachers conduct evaluations and follow up with fellow teachers to modify the learning situation, both in terms of methods, techniques, educational game tools, songs, poems, motivational words, and prayers which will be used in the next stage. The goal is to stimulate the spirit of the movement in children.

The teacher's low motivation is one factor that affects the low results of throwing-cathing the plastic ball treatment in the first cycle. This condition occurs because teachers feel lacking in terms of experience, knowledge, motivation, and skills regarding developing kinesthetic abilities in children. Teachers have an essential role as controllers or directors of skills and knowledge mastered by students (Siron et al., 2020; Syarifudin, 2020). So a teacher is expected to have knowledge, experience, skills, and motivation in terms of education to create a pleasant learning atmosphere for children (Mulyono et al., 2017; Yetti \& Juniasih, 2016).

Play is one of the fun learning methods for children. Play is an activity that is dominated by moving (Junaedi \& Nugroho, 2014). Play is also an essential expression of development for children (Ali et al., 2017; Mcclure et al., 2017; Sari, 2014; Wahyuni et al., 2020). Children will be more creative and imaginative through play (Ningtyas, 2014; Park et al., 2017). Moreover, through playing, children will learn how to socialize, feel various emotions, measure abilities and potential, train to follow the rules, honest, train physical and spiritual functions, and present their fantasies, talents, and tendencies (Anggraini, 2014; Park et al., 2017).

Throwing and catching is a skill that children must develop naturally because it will benefit their growth and development in the future (Nainggolan \& Manalu, 2020). According to Kamtini \& Tanjung, the basic movement of throwing manipulation is divided into two, namely throwing with one hand above the shoulder and throwing with one hand below (Kamtini \& Husni, 2005). Techniques for throwing the ball include throwing the ball soaring, horizontally, and rotating on the ground. The technique of catching the ball can be done by catching the ball with both hands correctly (Mulyaningsih et al., 2010).

The data obtained regarding the development of kinesthetic abilities in group A of Ria Pembangunan Sentani Kindergarten are as follows. 
Table 1 Processed at the $1^{\text {st }}$ Cycle

\begin{tabular}{|c|c|c|c|c|c|}
\hline \multirow[b]{2}{*}{ No } & \multirow[b]{2}{*}{ Name } & \multicolumn{3}{|c|}{ Assessed Aspects } & \multirow[b]{2}{*}{$\begin{array}{c}\text { Percentage } \\
(\%)\end{array}$} \\
\hline & & $\begin{array}{c}\text { Throwing with one } \\
\text { hand over the shoulder }\end{array}$ & $\begin{array}{c}\text { Throwing with one } \\
\text { hand down }\end{array}$ & $\begin{array}{l}\text { Catch } \\
\text { the ball }\end{array}$ & \\
\hline 1 & A A & $* *$ & $* * *$ & $* *$ & 58.33 \\
\hline 2 & $\mathrm{AV}$ & $* * *$ & * & ** & 50 \\
\hline 3 & $\mathrm{AE}$ & * & $* *$ & $* * * *$ & 58.33 \\
\hline 4 & CA & $* * * *$ & $* * * *$ & ** & 83.33 \\
\hline 5 & $\mathrm{CE}$ & * & * & * & 25 \\
\hline 6 & DA & * & $* * *$ & * & 41.67 \\
\hline 7 & DW & $* * * *$ & ** & $* * *$ & 75 \\
\hline 8 & ED & * & * & ** & 33.33 \\
\hline 9 & GD & * & * & * & 25 \\
\hline 10 & HA & $* *$ & $* * * *$ & ** & 66.67 \\
\hline 11 & IJ & * & * & * & 25 \\
\hline 12 & MM & * & ** & $* * *$ & 50 \\
\hline \multicolumn{2}{|c|}{ Average } & 45.83 & 52.08 & 50 & 49.30 \\
\hline
\end{tabular}

Source of data: researcher's primary data

Notes:

$* * * * \quad$ : It was developing very well

*** : It was developing as expected

** : : It was starting to develop

* $\quad$ : It had not developed

Table 1 shows that the kinesthetic ability of children in group A1 Ria Pembangunan Kindergarten is low, as evidenced by the initial kinesthetic ability reaching $49.30 \%$, including the aspect of throwing with one hand over the shoulder reaching $45.83 \%$, the aspect of throwing with one hand on the other under $52.08 \%$, and the aspect of catching the ball $50 \%$.

Table 2 shows that after thematic learning through the throwing-catching game using the small plastic ball, kinesthetic abilities increased to $82.64 \%$, including the aspect of throwing with one hand over the shoulder reaching $81.22 \%$, the aspect of throwing with one hand below reaching $85.42 \%$, and the aspect of catching the ball reaches $83.33 \%$.

Based on the results of the second cycle, it can be seen that there has been an increase in kinesthetic abilities through the game of throwing and catching a small plastic ball at TK Ria Pembangunan Sentani. Therefore, the study was stopped in the second cycle because the achievement indicator had reached more than $75 \%$, a sign of increased kinesthetic abilities in grade A children at Ria Pembangunan Sentani Kindergarten. The indicators used are throwing movements with one hand above the shoulder, throwing with one hand below, and catching the ball with both hands. 
Table 2. Processed at the $2^{\text {nd }}$ Cycle

\begin{tabular}{|c|c|c|c|c|c|}
\hline \multirow[b]{2}{*}{ No } & \multirow[b]{2}{*}{ Name } & \multicolumn{3}{|c|}{ Assessed Aspects } & \multirow[b]{2}{*}{ Percentage (\%) } \\
\hline & & $\begin{array}{c}\text { Throwing with one } \\
\text { hand over the } \\
\text { shoulder }\end{array}$ & $\begin{array}{c}\text { Throwing with one } \\
\text { hand down }\end{array}$ & $\begin{array}{l}\text { Catch the } \\
\text { ball }\end{array}$ & \\
\hline 1 & A A & $* * * *$ & $* * * *$ & $* * *$ & 91.67 \\
\hline 2 & $\mathrm{AV}$ & $* * * *$ & $* * *$ & $* * *$ & 83.33 \\
\hline 3 & $\mathrm{AE}$ & $* * *$ & $* * *$ & $* * * *$ & 83.33 \\
\hline 4 & CA & $* * * *$ & $* * * *$ & $* * *$ & 91.67 \\
\hline 5 & $\mathrm{CE}$ & *** & $* * * *$ & ** & 75 \\
\hline 6 & DA & $* * *$ & $* * * *$ & $* * * *$ & 75 \\
\hline 7 & DW & $* * * *$ & $* * *$ & $* * *$ & 91.67 \\
\hline 8 & ED & $* *$ & $* * *$ & $* * * *$ & 75 \\
\hline 9 & GD & $* * *$ & $* * *$ & $* * *$ & 75 \\
\hline 10 & HA & $* * *$ & $* * * *$ & $* * * *$ & 91.67 \\
\hline 11 & IJ & $* * *$ & $* * *$ & $* * *$ & 75 \\
\hline 12 & $\mathrm{MM}$ & $* * *$ & $* * *$ & $* * * *$ & 83.33 \\
\hline $\mathrm{Av}$ & erage & 81.22 & 85.42 & 83.33 & 82.64 \\
\hline
\end{tabular}

Source of data: researcher's primary data

Notes:

$\begin{array}{ll}* * * * & : \text { It was developing very well } \\ * * * & : \text { It was developing as expected } \\ * * & : \text { It was starting to develop } \\ * & : \text { It had not developed }\end{array}$

In throwing with one hand over the shoulder in the third cycle II, most children experienced increased development. Eleven children have developed as expected. It is just that there is one child who has started to develop, namely ED. On the other hand, AA, AV, CA, and DW experienced a significant improvement. They can practice adequately and correctly, even if only through one example of the movement. While ED still needs the help of the teacher in throwing the ball. Here are the steps for throwing with one hand over the shoulder: 1) Taking the ball from the basket, 2) left foot forward half a step, 3) body position slightly leaning back, 3) left hand stretched forward at shoulder level.

In the aspect of throwing with one hand down, all students experienced a tremendous increase in development. Five of them are developing very significant, namely AA, CA, CE, DA, and HA. They managed to make the throwing motion with one hand down, even though only one time was given an example. Here are the steps for throwing with one hand below: 1) Picking up the ball in the basket, 2) standing, 3) left foot half step forward, 4) left hand below, 5) right hand holding the 
ball while raised parallel to the right ear, then hold the breath halfway and the ball is thrown forward while exhaling.

In catching the ball with both hands, almost all students experienced a tremendous increase in development. Four of them, AE, DA, ED, and MM, showed excellent development. However, there is one child who has started to develop, namely CE. CE is less energetic and still slow in moving, so CE has not been able to follow the steps of catching the ball well. Here are the steps to catch the ball with both hands: 1) Standing position, with both legs stretched parallel to the shoulders, 2) arms bent above the navel, 3) eyes fixed on the direction of the ball, 4) palms stretched out when receiving the ball, 5) put your hands together to hold the ball, so it doesn't fall to the floor.

Kinesthetic development in children is essential to be developed so that children can master it. Meanwhile, if the child's kinesthetic development is not appropriate, it will have an impact on a lack of self-confidence and cause emotional instability in children due to the low self-esteem experienced by children (Farida, 2016).

\section{Conclusion}

Based on the results of the research that has been done, it can be concluded that the game of throwing and catching small plastic balls for class A students at TK Ria Pembangunan Sentani can improve students' kinesthetic abilities. This condition can be proven by an increase in the percentage in the second cycle. It was reaching more than $75 \%$, which is a sign of an increase in kinesthetic ability. Children's kinesthetic intelligence should be stimulated from an early age both by parents and educational institutions. Learning methods and techniques that are varied and fun are also needed so that children's development can be achieved as expected.

The limitation of this investigation is the researcher's depth of focus due to the inadequate time available. Besides, the relatively small number of participants still requires exploring more extensive data. Improving the kinesthetic ability through throwing-cathing using small balls will be more comprehensive if more participants are involved.

\section{References}

Ali, A., Pigou, D., Clarke, L., \& McLachlan, C. (2017). Literature Review on Motor Skill and Physical Activity in Preschool Children in New Zealand. Advances in Physical Education, 07(01), 10-26. https:/ / doi.org/10.4236/ape.2017.71002

Anggraini, D. D. (2014). Peningkatan Kecerdasan Kinestetik Melalui Kegiatan Bermain Sirkuit Dengan Bola (Penelitian Tindakan di Kelompok A TK Al 
Muhajirin Malang Jawa Timur, Tahun 2015). Jurnal Pendidikan Usia Dini, 2(2), 6575 .

Beaty, J. J. (2013). Observasi Perkembangan Anak Usia Dini. Kencana Prenada Media Group.

Bellows, L. L., Davies, P. L., Courtney, J. B., Gavin, W. J., Johnson, S. L., \& Boles, R. E. (2017). Motor skill development in low-income, at-risk preschoolers: A community-based longitudinal intervention study. Journal of Science and Medicine in Sport, 20(11), 997-1002. https://doi.org/10.1016/j.jsams.2017.04.003

Brian, A., \& Taunton, S. (2018). Effectiveness of motor skill intervention varies based on implementation strategy. Physical Education and Sport Pedagogy, 23(2), 222233. https:/ / doi.org/10.1080/17408989.2017.1413709

Dinar, P. W. (2008). Psikologi Anak Usia Dini. Indeks.

Farida, A. (2016). Urgensi Perkembangan Motorik Kasar pada Perkembangan Anak Usia Dini. Jurnal Raudhah, 4(2), 10-38.

Farmer, O., Belton, S., \& O'Brien, W. (2017). The Relationship between Actual Fundamental Motor Skill Proficiency, Perceived Motor Skill Confidence and Competence, and Physical Activity in 8-12-Year-Old Irish Female Youth. Sports, 5(4), 74. https://doi.org/10.3390/sports5040074

Fitriana, A. A., Azizah, E. N., \& Tanto, O. D. (2021). Pengaruh Media Sosial Tik Tok Terhadap Kecerdasan Kinestetik Anak Usia Dini. JCE (Journal of Childhood Education), 5(1), 101.

Hasibuan, N. R. F., Fauzi, T., \& Novianti, R. (2020). Pengaruh kegiatan senam irama terhadap kecerdasan kinestetik pada anak kelompok $\mathrm{b}$ tk mustabaqul khoir Palembang. Jurnal Pendidikan Anak, 9(2), 118-123. https://doi.org/10.21831/jpa.v9i2.33564

Junaedi, S., \& Nugroho, I. H. (2014). Permainan Tradisional “Betengan" sebagai Metode Permainan untuk Pengembangan Kecerdasan Kinestetik Anak Usia Dini. Nusantara of Research, 1(1), 38-44.

Kamtini, \& Husni, T. W. (2005). Bermain Melalui Gerak dan Lagu di Taman Kanak-Kanak. Depdiknas.

Khaironi, M. (2018). Perkembangan Anak Usia Dini. Jurnal Golden Age, 2(01), 01. https://doi.org/10.29408/goldenage.v2i01.739

Logan, S. W., Robinson, L. E., Wilson, A. E., \& Lucas, W. A. (2012). Getting the fundamentals of movement: A meta-analysis of the effectiveness of motor skill interventions in children. Child: Care, Health and Development, 38(3), 305-315. https://doi.org/10.1111/j.1365-2214.2011.01307.x 
Mcclure, E. R., Guernsey, L., Clements, D. H., Bales, S. N., Nichols, J., Kendall-Taylor, N., \& Levine, M. H. (2017). STEM starts early: Grounding science, technology, engineering, and math education in early childhood. The Joan Ganz Cooney Center at Sesame Workshop.

Mukherjee, S., Ting Jamie, L. C., \& Fong, L. H. (2017). Fundamental Motor Skill Proficiency of 6- to 9-Year-Old Singaporean Children. Perceptual and Motor Skills, 124(3), 584-600. https:/ / doi.org/10.1177/0031512517703005

Mulyaningsih, A., Kriswanto, E. S., Yudanto, \& Jatmika, H. (2010). Pendidikan Jasmani Olahraga dan Kesehatan Untuk Kelas V SD/MI. Pusat Perbukuan Kementerian Pendidikan Nasional.

Mulyono, R., Suhyanto, O., Siron, Y., \& Rochimah, N. (2017). Pengaruh Intensi, Motivasi, Dan Pemahaman Guru Terhadap Impementasi Pendidikan Inklusif. JPUD - Jurnal Pendidikan Usia Dini, 11(2), 293-307. https://doi.org/10.21009/jpud.112.08

Musfiroh, T. (2008). Cerdas Melalui Bermain. PT Grasindo.

Nainggolan, A. P., \& Manalu, R. B. B. (2020). Modifikasi Alat Bantu Pembelajaran Melempar dan Menangkap dalam Hasil Belajar Permainan Softball. Jurnal Ilmiah Pendidikan Jasmani, 4 (1) 2020, 4(1). https:/ / doi.org/ E-ISSN:2685-6514

Ningtyas, F. Y. (2014). Metode Bermain Lego Dalam Upaya Menumbuhkembangkan Kecerdasan Kinestetik Pada Anak Usia Dini, Studi Kasus di Lembaga Pendidikan Manusia Unggul. Jurnal Empowerment, 4(2), 128-134.

Nursiti, D., Hamid, L., \& Nurhidayah, N. (2020). Efektivitas Metode gerak dan lagu untuk meningkatkan kecerdasan Kinestetik pada anak usia dini. Keislaman Dan Pendidikan, 1(1), 1-13.

Park, M. H., Dimitrov, D. M., Patterson, L. G., \& Park, D. Y. (2017). Early Childhood Teachers' Beliefs About Readiness for Teaching Science, Technology, Engineering, and Mathematics. Journal of Early Childhood Research, 15(3), 275-291. https://doi.org/10.1177/1476718X15614040

Rahayu, E. D., \& Firmansyah, G. (2019). Pengembangan Permainan Tradisional Lompat Tali Untuk Meningkatkan Kinestetic Intelegency Pada Anak Usia 11-12 Tahun. Jendela Olahraga, 4(2), 8. https:// doi.org/10.26877/jo.v4i2.3611

Respati, R., Nur, L., \& Rahman, T. (2018). Gerak Dan Lagu Sebagai Model Stimulasi Pengembangan Kecerdasan Kinestetik Anak Usia Dini. JPUD - Jurnal Pendidikan Usia Dini, 12(2), 321-330. https:/ / doi.org/10.21009/jpud.122.13

Rochimah, N., Handini, M. C., \& Hapidin. (2020). Effect of family factor and children ' s school readiness in integrated waste treatment places: path analysis. JECE (Journal of Early Childhood Education), 2(2), 97-112. 
Rohmah, A. A., \& Jauhari. (2020). Mengembangkan Kecerdasan Kinestetik Anak Usia Dini Melalui Pembelajaran Multiple Intelligences. Jurnal Pendidikan Islam Anak Usia Dini, 1(1), 32-41.

Rosmayanti, E., Dwi, F., Santana, T., \& Al, R. A. (2021). Pembelajaran Senam Fantasi Untuk Meningkatkan Kecerdasan Kinestetik Anak Usia 5-6 Tahun. 4(3), 242-250.

Rozie, F., Safitri, D., \& Haryani, W. (2019). Peran Guru Dalam Penanganan Perilaku Anak Hiperaktif Di Tk Negeri 1 Samarinda. JECE (Journal of Early Childhood Education), 1(2), 53-59. https://doi.org/10.15408/jece.v1i2.12874

Safitri, A., Kabiba, K., Nasir, N., \& Nurlina, N. (2020). Manajemen Pembelajaran bagi Anak Usia Dini dalam Meningkatkan Kualitas Pembelajaran. Jurnal Obsesi: Jurnal Pendidikan Anak Usia Dini, 5(2), 1209-1220. https://doi.org/10.31004/obsesi.v5i2.811

Sari, M. (2014). Peningkatan Kecerdasan Kinestetik Melalui Kegiatan Bermain Air. Jurnal Pendidikan Usia Dini, 8, 373-382.

Siron, Y., Nuryanah, A. I., Huraerah, H., \& Rahmani, N. F. (2020). Wajah TK Berbasis Islam: Kesiapan Guru dalam Menerapkan Pembelajaran STEM. Al Hikmah: Indonesian Journal of Early Childhood Islamic Education, 4(2), 171-192.

Sobariah, S., \& Santana, F. D. T. (2019). Meningkatkan Kecerdasan Kinestetik Anak Usia Dini Melalui Media Tari Mapag Layung. CERIA (Cerdas Energik Responsif Inovatif Adaptif), 2(6), 370. https:/ / doi.org/10.22460/ceria.v2i6.p370-375

Sujiono, \& Nurani, Y. (2008). Konsep Dasar Pendidikan Anak Usia Dini. Indeks.

Syaikhu, A., \& Napis, A. D. (2020). Permainan Tradisional Betawi untuk Meningkatkan Kemampuan Kognitif Siswa di TK Mutiara. JECE (Journal of Early Childhood Education), 2(1), 84-96. https:// doi.org/10.15408/jece.v2i1.15576

Syarifudin, A. S. (2020). Impelementasi Pembelajaran Daring Untuk Meningkatkan Mutu Pendidikan Sebagai Dampak Diterapkannya Social Distancing. Jurnal Pendidikan Bahasa Dan Sastra Indonesia Metalingua, 5(1), 31-34. https://doi.org/10.21107/ metalingua.v5i1.7072

Umami, A., Kurniah, N., \& Delrefi. (2016). Peningkatan Kecerdasan Kinestetik Anak melalui Permainan Estafet. Jurnal Ilmah Potensia, 1(1), 15-20.

Utesch, T., Bardid, F., Büsch, D., \& Strauss, B. (2019). The Relationship Between Motor Competence and Physical Fitness from Early Childhood to Early Adulthood: A Meta-Analysis. Sports Medicine, 49(4), 541-551. https://doi.org/10.1007/s40279-019-01068-y

Viana, R. O., \& Jauhari. (2017). Pembelajaran Gerak dan Lagu untuk Meningkatkan Kecerdasan Kinestetik Anak Usia Dini. Pedagogi, 3, 58-69. 
Wahyuni, I. W., Muazimah, A., \& Misda. (2020). Pengembangan motorik kasar anak melalui permainan tradisional. 8(1), 61-68.

Yetti, E., \& Juniasih, I. (2016). Implementasi Model Pembelajaran Tari Pendidikan untuk Meningkatkan Kecerdasan Kinestetik Anak Usia Dini melalui Metode Pembelajaran Aktif (Pengembangan Model di Taman Kanak-Kanak Labschool Jakarta pada Kelompok B). JPUD - Jurnal Pendidikan Usia Dini, 10(2), 385-400. https://doi.org/10.21009/jpud.102.11

Yuningsih, R., Akmariani, C., Fitriani, W., \& Batusangkar, P. I. (2019). Pengaruh Senam Irama Terhadap Kecerdasan Kinestetik Pada Anak Di Tk Kurnia Illahi Kabupaten Tanah Datar. Tumbuh Kembang: Kajian Teori Dan Pembelajaran PAUD, 6(1), 11-18. 